УДК 630.1

\title{
Growth and Development of the Introduced Picea L. (Karst.) Species in the Taiga Zone (Karelia)
}

\author{
Ivan T. Kishchenko* \\ Petrozavodsk State University \\ Petrozavodsk, Russian Federation
}

Received 19.01.2019, received in revised form 03.06.2020, accepted 20.12.2020

\begin{abstract}
The study was conducted in the Botanical Garden of Petrozavodsk State University (South Karelia, the middle taiga subzone) from April to October during 1988-2016. The following representatives of the genus Picea were investigated: four introduced species (Picea glauca (Moench) Voss [syn. P. canadensis Britt.], P. pungens Engelm. f. viridis Regel., P. obovata Ledeb., and P. mariana Britt.) and one native species (P. abies (L.) Karst.). The growth of $P$. abies shoots starts 1-4 weeks earlier and ends 1-3 weeks later compared to the introduced species. The earliest culmination of shoot growth is observed in $P$. glauca and $P$. obovata and the latest in $P$. abies. The longest shoots are formed by $P$. abies. The growth dynamics of shoots differs considerably between the introduced species and the native species. The dates of the beginning and the culmination of the shoot growth in the studied species are to a certain extent affected by the temperature of the air. P. abies needles begin to grow 1-2 weeks earlier than the needles of the introduced species. The earliest culmination of needle growth is observed in P. obovata and P. glauca and the latest in P. pungens. P. abies and P. pungens show the largest needle length increment, while in the other species, it is 2-4 times smaller. The longest needles are formed in $P$. pungens and P. abies. There is a noticeable difference in needle growth dynamics between the introduced species and the native species. The dates on which needles begin to grow are largely determined by the temperature of the air. The temperature of the air and solar radiation produce a substantial effect on the time of occurrence of most phenophases in the studied Picea species. P. pungens and P. glauca were found to be the most promising spruce species for residential landscaping and creation of artificial plant communities in Karelia.
\end{abstract}

Keywords: introduction, Picea, growth, development, Karelia.

(C) Siberian Federal University. All rights reserved

This work is licensed under a Creative Commons Attribution-NonCommercial 4.0 International License (CC BY-NC 4.0).

* Corresponding author E-mail address: ivanki@karelia.ru ORCID: 0000-0002-1039-1020 
Acknowlegements. The research was supported by RFBR (project 18-44-100002 p_a).

Citation: Kishchenko I. T. Growth and development of the introduced Picea L. (Karst.) species in the taiga zone (Karelia). J. Sib. Fed. Univ. Biol., 2021, 14(2), 238-258. DOI: 10.17516/1997-1389-0348

\title{
Рост и развитие интродуцированных видов Picea L (Karst.) в таежной зоне (Карелия)
}

\author{
И. Т. Кищенко \\ Петрозаводский государственный университет \\ Российская Федерация, Петрозаводск
}

\begin{abstract}
Аннотация. Исследования проводили в 1988-2016 гг. с апреля по октябрь в Ботаническом саду Петрозаводского государственного университета (Южная Карелия, подзона средней тайги). Объектами исследований служили представители рода Picea: четыре интродуцированных вида (Picea glauca (Moench) Voss [syn. P. canadensis Britt.], P. pungens Engelm. f. viridis Regel., P. obovata Ledeb., P. mariana Britt.) и один аборигенный (P. abies (L.) Karst.). Рост побегов у P. abies начинается на 1-4 недели раньше, а заканчивается на 1-3 недели позже, чем у интродуцентов. Ранее всего кульминация прироста побегов происходит у P. glauca и P. obovata, а позже всего - у P. abies. Наиболее длинные побеги формируются у $P$. abies. Динамика прироста побегов у интродуцентов значительно отличается от таковой у аборигенного вида. Начало роста побегов и кульминация их прироста у изучаемых видов в определенной мере зависит от температурного режима воздуха. Рост хвои у $P$. abies начинается на 1-2 недели раньше, чем у интродуцированных видов. Ранее всего кульминация ее прироста происходит у P. obovata и P. glauca, а позже всего - у P. pungens. Наибольшая величина прироста хвои характерна для P. abies и P. pungens, у других видов она в 2-4 раза меньше. Наиболее длинная хвоя формируется у P. pungens и P. abies. Динамика прироста хвои у интродуцентов существенно отличается от таковой у аборигенного вида. Начало роста хвои в значительной степени зависит от температурного режима воздуха. Существенное влияние на сроки прохождения большинства фенофаз изученных видов рода Picea оказывает температура воздуха и солнечная радиация. Наиболее перспективными для озеленения населенных пунктов и создания культурценозов в Карелии оказались P. pungens u P. glauca.
\end{abstract}

Ключевые слова: интродукция, Picea, рост, развитие, Карелия.

Благодарности. Исследование выполнено при поддержке РФФИ (проект 18-44-100002 p_a).

Цитирование: Кищенко, И. Т. Рост и развитие интродуцированных видов Picea L (Karst.) в таежной зоне (Карелия) / И. Т. Кищенко // Журн. Сиб. федер. ун-та. Биология, 2021. 14(2). С. 238-258. DOI: 10.17516/1997-1389-0348 


\section{Введение}

Большинство аборигенных видов древесных растений таежной зоны России обладают низкой устойчивостью к поллютантам. Между тем, многие виды семейства Pinaceae других географических районов устойчивы к загрязнению урбаносреды и к тому же долговечны и декоративны в течение круглого года (Встовская, 1983; Плотникова, 1983; Лапин, 1987; Бабич, 2008; Стецук и др., 2011; Rousselet et al., 2015). Некоторые из них даже показывают повышенную продуктивность по сравнению с местными видами и способны к натурализации (Калуцкий, Болотов, 1983; Мамаев, Махиев, 1996; Ботенков, Попова, 1997). Кроме того, интродукция растений способна значительно повысить биологическое разнообразие окружающей среды (Мамаев, Махиев, 1996; Bradshaw, 1995; Исаев и др., 1997; Буданцев, 1999; Морякина, 1998; Сикура, 1998). Все это свидетельствует о необходимости интродукции хвойных растений и оценки их перспективности. Перспективность интродукции устанавливается путем исследования адаптаций, происходящих у испытуемых растений в новых условиях (Базилевская, 1964; Ворошилов, 1960). Как показали исследования ряда авторов (Встовская, 1983; Плотникова, 1983; Трулевич, 1991; Шкутко, 1991; Кищенко, 2000), именно особенности роста и развития растений наиболее достоверно характеризуют состояние интродуцентов.

К настоящему времени особенности роста и развития хвойных интродуцентов изучены далеко не полно и нуждаются в уточнении и дальнейшем изучении. Характер и степень влияния экологических факторов на их рост и развитие остаются во многом неясными. В Карелии подобные исследования интродуцентов рода Picea ранее не проводились.

Целью настоящих исследований являлось выяснение особенностей роста и раз- вития некоторых интродуцированных видов Picea L. (Karst.) под влиянием главнейших климатических факторов и оценка их перспективности.

\section{Материалы и методы}

Объектами исследований служили 5 видов рода Picea. Характеристика объектов исследований приведена в табл. 1.

Изучали интродуцированные виды хвойных растений в Ботаническом саду Петрозаводского государственного университета. Наблюдения за развитием растений проводили в 1988-2016 гг., а за ростом - в 1988-1990 гг. Каждый изучаемый вид представлен групповой посадкой из 10-25 деревьев. Условия водного, минерального и светового режимов у всех изучаемых видов одинаковые. Размещение и густота посадок в каждой группе идентичны.

Picea abies занимает обширный ареал в Западной Европе. В России этот вид распространен в северо-западных, западных и центральных районах европейской части. Picea obovata растет в европейской части России в северных, северо-восточных районах, а также на Урале, в Сибири (кроме Крайнего Севера), на Дальнем Востоке (юг Охотского побережья, бассейн верхнего и нижнего течения р. Амура). Ареал Picea pungens - Запад Северной Америки (Скалистые Горы), где она произрастает на высоте 2-3 тыс. м над уровнем моря. Picea glauca растет в Северной Америке (Канада и северные штаты США). Родина Picea mariana - территория Северной Америки от Лабрадора и Аляски на севере до Виргинии и Висконсина на юге.

Наблюдения за ростом побегов и хвои проводили по методике А.А. Молчанова и В. В. Смирнова (1967). С помощью линейки измеряли длину осевых побегов (второго порядка ветвления) с юго-западной части кро- 
Таблица 1. Характеристика объектов исследований

Table 1. Characteristics of research objects

\begin{tabular}{|l|c|c|c|c|}
\hline \multicolumn{1}{|c|}{ Виды } & $\begin{array}{c}\text { Место происхождения } \\
\text { саженцев (ботсад-город) }\end{array}$ & $\begin{array}{c}\text { Возраст, } \\
\text { лет }\end{array}$ & $\begin{array}{c}\text { Средняя } \\
\text { высота, м }\end{array}$ & $\begin{array}{c}\text { Наличие } \\
\text { семеношения }\end{array}$ \\
\hline $\begin{array}{l}\text { Picea glauca } \text { (Moench) Voss } \\
\text { [syn. P. canadensis Britt.] }\end{array}$ & С.-Петербург & 42 & 16,7 & есть \\
P. pungens Engelm. f. viridis Regel. & Бухарест & 45 & 13,7 & есть \\
P. obovata Ledeb. & Минск & 32 & 9,2 & нет \\
P. mariana Britt. & Бухарест & 28 & 7,1 & нет \\
P. abies (L.) Karst. & Петрозаводск & 31 & 8,4 & нет \\
\hline
\end{tabular}

ны на высоте около 2 м с момента набухания почек до заложения зимующих почек через каждые 2-3 сут. По каждому виду выбирали по 10 учетных деревьев, у каждого из которых промаркировали по 25 побегов. Таким образом, объем выборки по каждому сроку наблюдения составлял 250 побегов. Рост промаркированной хвои с помощью линейки изучали в верхней части тех же побегов, с тем же временным интервалом. Объем выборки тот же, что и для побегов. Величину суточного прироста побегов и хвои определяли как разницу в их длине (среднеарифметической) между последующим и предшествующим наблюдениями, деленную на число суток этого периода.

Фенологические наблюдения проводили, используя методические указания Н. Е. Булыгина (1979), через каждые 2-3 сут. Фиксировали время прохождения таких фенофаз, как набухание и разверзание вегетативных почек, начало и окончание линейного роста побегов, опробковение ростовых побегов, обособление хвои на побегах, завершение роста и вызревание, расцвечивание и опадение хвои, обособление на побегах почек. Фенофаза считалась наступившей, если она отмечалась не менее чем у 30 \% побегов всех особей исследуемого вида. Отсутствие данных по развитию репродуктивной сферы у большинства изучаемых видов объясняется сравнительно небольшим возрастом особей, а также большими временными интервалами между семенными годами, не позволяющими использовать статистическую обработку данных.

Оценку перспективности интродукции древесных растений по данным визуальных наблюдений проводили по методике П. И. Лапина и С. В. Сидневой (1973). При этом учитывали такие показатели, как степень ежегодного вызревания побегов, зимостойкость, сохранение габитуса, побегообразовательная способность, регулярность прироста осевых побегов, способность к генеративному развитию, возможность размножения в культуре, общая оценка перспективности.

Климатические данные (суммарная солнечная радиация; атмосферные осадки; среднесуточная, минимальная и максимальная относительная влажность воздуха; среднесуточная, минимальная и максимальная температура воздуха) регистрировались на Сулажгорской метеостанции (Карельская гидрометеорологическая обсерватория), расположенной в 3 км к юго-западу от Ботанического сада. Сумму положительных температур рассчитывали как сумму среднесуточных 
температур с момента перехода температуры через 0 ㄷ до начала или прекращения какойлибо фенофазы.

Статистическая обработка материалов наблюдений за интродуцентами показала, что при определении среднеарифметической величины прироста побегов ошибка среднего значения составляет 4-6 \%, а коэффициент вариации - 14-20\%; хвои - соответственно 3-5 и 10-15\%; фенодат - 5-6 и 18-24\%. По результатам наблюдений за ростом и развитием растений, а также метеорологических условий сформировали банк данных, обработанный с помощью рекомендуемых для этих целей корреляционного и регрессионного методов анализа (Зайцев, 1981). Длина корреляционного ряда при изучении роста побегов и хвои (число наблюдений за вегетацию) - от 25 до 35, а при изучении развития (число лет) -28 .

\section{Результаты и обсуждение}

Линейный рост побегов

Проведенные исследования позволили установить, что сроки начала роста побегов изучаемых видов рода Picea могут варьировать по годам в пределах 2-3 недель. Подобную изменчивость наблюдал и Н.В. Шкутко (1991). Наиболее стабильны сроки начала данной фенофазы у $P$. abies. При сравнении отдельных видов Picea выяснилось, что раньше всего начинается рост побегов у аборигенного вида - 30 IV-11 V. Через 6-14 сут их рост отмечается у $P$. glauca. Остальные виды вступают в эту фазу в конце мая или в начале июня (табл. 2).

Таблица 2. Температурный режим воздуха в период роста побегов у различных видов рода Рісеа Table 2. Air temperature in the period of growth of shoots of different Picea species

\begin{tabular}{|c|c|c|c|c|c|c|c|c|c|c|}
\hline \multirow[b]{2}{*}{ Виды } & \multirow[b]{2}{*}{$\begin{array}{c}\text { Годы } \\
\text { наблю- } \\
\text { дений }\end{array}$} & \multicolumn{3}{|c|}{ Начало роста } & \multicolumn{3}{|c|}{ Кульминация прироста } & \multicolumn{3}{|c|}{ Окончание роста } \\
\hline & & 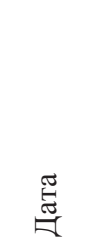 & 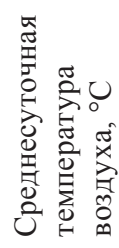 & 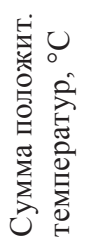 & $\underset{\stackrel{E}{E}}{\stackrel{\Xi}{\sigma}}$ & 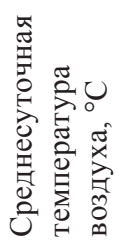 & 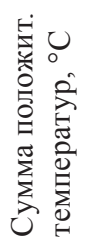 & $\stackrel{\widetilde{\sigma}}{\vec{\sigma}}$ & 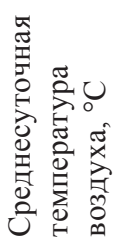 & 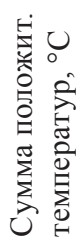 \\
\hline \multirow{3}{*}{ P. pungens } & 1988 & $29 \mathrm{~V}$ & 17,2 & 335 & $24-26 \mathrm{VI}$ & 22,2 & 738 & $25 \mathrm{VII}$ & 14,5 & 1296 \\
\hline & 1989 & $16 \mathrm{~V}$ & 13,2 & 232 & $13-15 \mathrm{VI}$ & 11,0 & 695 & $25 \mathrm{VII}$ & 15,0 & 1398 \\
\hline & 1990 & $4 \mathrm{VI}$ & 17,2 & 172 & $4-6 \mathrm{VI}$ & 12,5 & 298 & $2 \mathrm{VII}$ & 10,6 & 522 \\
\hline \multirow{3}{*}{ P. glauca } & 1988 & $18 \mathrm{~V}$ & 14,5 & 192 & $10-12 \mathrm{VI}$ & 12,2 & 502 & $25 \mathrm{VII}$ & 14,5 & 1296 \\
\hline & 1989 & $6 \mathrm{~V}$ & 9,6 & 182 & $23-29 \mathrm{~V}$ & 13,8 & 444 & $25 \mathrm{VII}$ & 15,0 & 1398 \\
\hline & 1990 & $18 \mathrm{~V}$ & 14,4 & 184 & $29-31 \mathrm{~V}$ & 8,9 & 259 & $18 \mathrm{VI}$ & 14,4 & 384 \\
\hline \multirow{2}{*}{ P. mariana } & 1988 & $17 \mathrm{~V}$ & 10,8 & 178 & $10-12 \mathrm{VI}$ & 12,2 & 502 & $22 \mathrm{VII}$ & 20,4 & 1249 \\
\hline & 1990 & $29 \mathrm{~V}$ & 4,8 & 252 & $7-10 \mathrm{VI}$ & 7,4 & 352 & $2 \mathrm{VII}$ & 10,6 & 522 \\
\hline \multirow{3}{*}{ P. obovata } & 1988 & $29 \mathrm{~V}$ & 17,0 & 335 & $10-12 \mathrm{VI}$ & 12,2 & 502 & $25 \mathrm{VII}$ & 14,5 & 1296 \\
\hline & 1989 & $12 \mathrm{~V}$ & 9,4 & 242 & $23-29 \mathrm{~V}$ & 13,8 & 444 & 7 VII & 14,9 & 1103 \\
\hline & 1990 & $1 \mathrm{VI}$ & 7,6 & 268 & 4-6 VI & 12,5 & 298 & 2 VII & 10,6 & 522 \\
\hline \multirow{3}{*}{ P. abies } & 1988 & $11 \mathrm{~V}$ & 9,2 & 126 & $24-26 \mathrm{VI}$ & 22,2 & 738 & $25 \mathrm{VII}$ & 14,5 & 1296 \\
\hline & 1989 & $30 \mathrm{IV}$ & 8,5 & 131 & 16-19 VI & 15,6 & 758 & $29 \mathrm{VII}$ & 20,9 & 1475 \\
\hline & 1990 & $4 \mathrm{~V}$ & 5,0 & 121 & 15-17 VI & 8,6 & 379 & $6 \mathrm{VII}$ & 16,1 & 572 \\
\hline
\end{tabular}


Оказалось, что сроки прекращения роста побегов значительно варьируют по годам и различаются на 2-3 недели. По среднемноголетним данным, к рано прекращающим рост побегов (2-25 VII) следует отнести все интродуцированные виды. У аборигенного вида эта фенофаза заканчивается на 1-3 недели позже.

Установлено, что время кульминации прироста побегов также довольно заметно изменяется по годам. Быстрее всего эта фаза наступает у $P$. obovata и $P$. glauca (23 V-12 VI), а позже всего - у P. abies (15-26 VI).

Величина максимального прироста у разных видов рода Picea также варьирует в широких пределах (табл. 3). Его наибольшая величина (в среднем 4,7-4,9 мм/сут) обнаружена $y$ P. abies и P. pungens. У других изучаемых видов этот показатель меньше примерно в 1,5 раза. Следует подчеркнуть, что погодичная изменчивость величины максимального прироста побегов у этих видов может достигать $200-400 \%$.
Вполне понятно, что погодичные изменения в сроках начала и окончания роста побегов вызывают изменения и в продолжительности их формирования (Кищенко, 2000). В зависимости от периода наблюдений и вида растения последняя варьирует от 31 до 92 сут (табл. 3). Наиболее длительный рост характерен для P. abies (65-92 сут.), а самый короткий - для $P$. obovata (32-57 сут).

Обнаруженная значительная изменчивость в продолжительности и интенсивности роста побегов обусловливает и соответствующие различия в величине их годичного прироста. Длина побегов у P. obovata и P. pungens при этом может различаться в 3 раза, а у других видов - не более чем на 30-40 \%. Из данных табл. 3 следует, что наиболее длинные побеги (в среднем за 3 года 141 мм) формируются у $P$. abies. У других видов их длина составляет в среднем всего 69-84 мм. Анализ результатов исследований свидетельствует о том, что величина годичного прироста по-

Таблица 3. Основные характеристики прироста побегов у различных видов рода Picea

Table 3. The main characteristics of the growth of shoots in different Picea species

\begin{tabular}{|l|c|c|c|c|}
\hline \multirow{2}{*}{ Виды } & $\begin{array}{c}\text { Годы } \\
\text { наблюдений }\end{array}$ & $\begin{array}{c}\text { Максимальный } \\
\text { суточный прирост, мм }\end{array}$ & $\begin{array}{c}\text { Годичный прирост, } \\
\text { мм }\end{array}$ & $\begin{array}{c}\text { Продолжительность } \\
\text { роста, сут. }\end{array}$ \\
\hline \multirow{3}{*}{ P. pungens } & 1988 & $9,9 \pm 0,2$ & $142 \pm 6$ & $57 \pm 2$ \\
& 1989 & $2,0 \pm 0,1$ & $66 \pm 3$ & $70 \pm 3$ \\
& 1990 & $2,1 \pm 0,1$ & $39 \pm 2$ & $34 \pm 1$ \\
\hline P. glauca & 1988 & $4,2 \pm 0,1$ & $111 \pm 4$ & $58 \pm 3$ \\
& 1989 & $2,5 \pm 0,1$ & $75 \pm 3$ & $80 \pm 4$ \\
\hline \multirow{3}{*}{ P. mariana } & 1990 & $1,8 \pm 0,1$ & $47 \pm 2$ & $31 \pm 1$ \\
\hline \multirow{3}{*}{ obovata } & 1988 & $4,1 \pm 0,1$ & $85 \pm 4$ & $66 \pm 3$ \\
& 1990 & $1,7 \pm 0,1$ & $53 \pm 2$ & $34 \pm 1$ \\
\hline P. abies & 1988 & $7,0 \pm 0,3$ & $134 \pm 6$ & $57 \pm 3$ \\
& 1989 & $2,7 \pm 0,1$ & $73 \pm 3$ & $56 \pm 3$ \\
& 1990 & $1,8 \pm 0,1$ & $45 \pm 2$ & $32 \pm 1$ \\
\hline
\end{tabular}


бегов определяется в основном интенсивностью, а не продолжительностью роста (Кищенко, 2000). Так, длина побегов у P. pungens больше, чем у P. mariana, в среднем почти в 1,5 раза. При этом скорость роста побегов у первого вида в 1,5 раза больше, чем у второго, а продолжительность их формирования примерно одинакова.

Выяснилось, что рост побегов при самой низкой среднесуточной температуре воздуха $\left(4,8-10,8{ }^{\circ} \mathrm{C}\right)$ начинается у $P$. abies и P. mariana (табл. 2). Начало данной фенофазы у $P$. pungens наблюдается при наиболее высокой температуре $\left(13,2-17,2^{\circ} \mathrm{C}\right)$. У остальных видов этот процесс отмечается при 7,6-17,0 ${ }^{\circ} \mathrm{C}$. Следовательно, начало роста побегов у изучаемых видов Picea не обусловливается строго определенной температурой воздуха, о чем свидетельствуют ее различия в этот период в 5-7 ${ }^{\circ} \mathrm{C}$. Зависимость наступления данной фенофазы от температуры воздуха у различных видов хвойных растений обнаружена другими исследователями (Гортинский, Тарасов, 1977; Шкутко, 1991).

Выяснилось, что требовательность растений к температуре воздуха в период кульминации прироста побегов в значительной степени определяется их систематическим положением. Так, максимальный прирост побегов при температуре менее $9{ }^{\circ} \mathrm{C}$ может иметь место у P. abies, P. mariana и $P$. glauca. У других видов в эту фазу данный параметр среды выше на $2-13{ }^{\circ} \mathrm{C}$. Н.В. Шкутко (1991) также отмечает зависимость сроков кульминации прироста ели от температурного режима окружающей среды. Между тем сумма положительных температур в этот период варьирует в широких пределах $\left(300-700{ }^{\circ} \mathrm{C}\right)$, что указывает на отсутствие явного влияния данного параметра на кульминацию прироста побегов (Кищенко, 2000).
Как выявили исследования, для начала роста побегов показатель теплообеспеченности гораздо более стабилен, чем текущая температура воздуха. Оказалось, что рост побегов P. abies начинается при сумме положительных температур $121-131^{\circ} \mathrm{C}, P$. glaucaпри $182-192{ }^{\circ} \mathrm{C}$, P. pungens - при $172-335^{\circ} \mathrm{C}$. Подобная зависимость обнаружена Л. А. Фроловой (1979). Во время прекращения роста побегов среднесуточная температура воздуха и сумма положительных температур варьируют в широких пределах - соответственно $10,6-20,9$ и $384-1475{ }^{\circ} \mathrm{C}$. Эти данные свидетельствуют о том, что сроки прекращения деятельности апикальной меристемы у представителей рода Picea не связаны с температурным режимом, а скорее всего обусловлены генотипом вида. Результаты исследований Л.А. Фроловой (1979) показали, что для всех интродуцентов рода Рісеа тепла вполне достаточно для завершения годичного цикла развития вегетативных почек.

По сравнению с интродуцентами наиболее приспособленным к местным экологическим условиям является аборигенный вид $P$. abies, адекватно реагирующий на изменчивость факторов среды. Следовательно, о степени адаптации интродуцентов можно предположительно судить путем сравнения динамики их роста и роста аборигенного вида, используя корреляционный анализ. Оказалось, что однозначный вывод об искомой корреляции сделать невозможно, так как ее направление и сила весьма заметно изменяются по годам. Так, по данным 1988 г., прямая и часто тесная связь ( $\mathrm{r}=+0,6-+0,9$; $\mathrm{p}<0,05)$ обнаружена между динамикой прироста $P$. abies и аналогичным показателем всех изучаемых видов интродуцентов. По наблюдениям 1989 г., число таких связей снижается до 3, а в 1990 г. две из них характеризуются уже отрицательным направлением. Следова- 
тельно, можно предположить, что ростовые реакции интродуцентов, весьма сильно отличающиеся от таковых у аборигенного вида, имеют специфический характер в зависимости от конкретных экологических условий того или иного вегетационного периода.

Анализ результатов исследований свидетельствует об отсутствии достоверной корреляции между динамикой прироста побегов у изучаемых видов рода Picea и изменчивостью среднесуточной температуры воздуха за период наблюдений. Гораздо информативнее оказались данные этого анализа в отношении максимальных суточных температур. Так, между этими параметрами среды и приростом побегов у P.pungens установлена достоверная положительная корреляция ( $\mathrm{r}=+0,4-+0,6 ; \mathrm{p}<0,05)$. Полученные результаты дают возможность предположить, что температурный оптимум для этого вида находится выше значений данного фактора района интродукции. Также достоверная, но обратная по направлению корреляция $(\mathrm{r}=-0,4--0,7 ; \mathrm{p}<0,05)$ между интенсивностью роста побегов и максимальной температурой воздуха отмечена для P. abies и P. mariana. Beроятно, температурные условия района исследования для этого процесса у данных видов иногда несколько превышают норму. Результаты ряда авторов (Worrall, 1973; Damian et al., 1978; Шкутко, 1991) также свидетельствуют о том, что температура воздуха способна существенно влиять на динамику прироста побегов рода Picea. Отсутствие достоверной сопряженности прироста побегов и температуры воздуха у $P$. glauca и $P$. obovata скорее всего доказывает то, что решающее влияние на развитие вегетативной сферы этих видов имеют другие факторы.

При изучении корреляционных связей между динамикой прироста побегов и относительной влажностью воздуха выясни- лось, что для P. abies они либо недостоверны, либо незначительны по силе и положительны по направлению ( $\mathrm{r}=+0,2-+0,3 ; \mathrm{p}<0,05)$. Для других видов ели эти связи либо не выявляются, либо имеют отрицательное направление $(\mathrm{r}=-0,3--0,5 ; \mathrm{p}<0,05)$. Эти данные могут свидетельствовать о том, что аборигенный вид вполне адаптирован к режиму влажности воздуха, а для роста побегов интродуцентов ее значения в районе исследования часто находятся выше оптимальных. Возможно, механизм этого явления связан с уменьшением поступления в побеги органических веществ из-за падения скорости фотосинтеза, вызванного снижением интенсивности солнечной радиации. В условиях Карелии это явление наблюдается при увеличении облачности и влажности воздуха, чему обычно способствует выпадение атмосферных осадков. С этим хорошо согласуются и данные корреляционного анализа, показывающие, что для интродуцированных видов рода Picea количество атмосферных осадков явно превышает норму $(\mathrm{r}=-0,4--0,6 ; \mathrm{p}<0,05)$.

\section{Линейный рост хвои}

Проведенные исследования позволили установить, что сроки начала роста хвои у изученных видов рода Picea могут варьировать по годам в пределах 2-4 недель (табл. 4). Подобную изменчивость наблюдали и В.В. Смирнов (1964) и Н.В. Шкутко (1991). По мнению авторов, в годы с теплой и дружной весной разница в сроках распускания почек в пределах одного вида гораздо меньше, чем в годы с холодной и затяжной весной. Наши данные подтверждают этот вывод. При сравнении отдельных видов рода Picea выяснилось, что раньше всего начинается рост хвои у аборигенного вида - 13 V-3 VI. Остальные виды вступают в эту фазу на 3-14 сут позже (табл. 4). 
Таблица 4. Температурный режим воздуха в период роста хвои у различных видов рода Picea Table 4. Air temperature during the growth of needles in different Picea species

\begin{tabular}{|c|c|c|c|c|c|c|c|c|c|c|}
\hline \multirow[b]{2}{*}{ Виды } & \multirow[b]{2}{*}{$\begin{array}{c}\text { Годы } \\
\text { наблюдений }\end{array}$} & \multicolumn{3}{|c|}{ Начало роста } & \multicolumn{3}{|c|}{ Кульминация прироста } & \multicolumn{3}{|c|}{ Окончание роста } \\
\hline & & 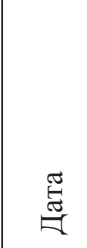 & 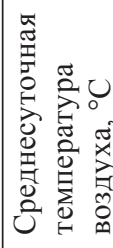 & 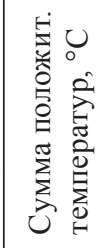 & $\stackrel{\pi}{[}$ & 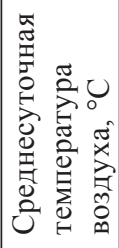 & 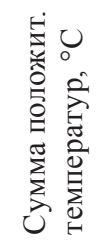 & $\stackrel{\sqrt[\pi]{\sigma}}{\pi}$ & 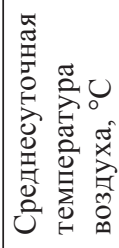 & 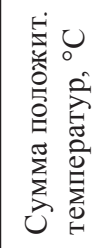 \\
\hline \multirow{3}{*}{ P. pungens } & 1988 & $7 \mathrm{VI}$ & 20,7 & 448 & $24-26 \mathrm{VI}$ & 22,2 & 738 & $22 \mathrm{VII}$ & 20,4 & 1249 \\
\hline & 1989 & $16 \mathrm{~V}$ & 13,2 & 292 & $13-15 \mathrm{VI}$ & 11,0 & 695 & $2 \mathrm{VIII}$ & 21,2 & 1556 \\
\hline & 1990 & $15 \mathrm{VI}$ & 16,8 & 450 & 29 VI-1 VII & 16,0 & 520 & $9 \mathrm{VII}$ & 22,5 & 633 \\
\hline \multirow{3}{*}{ P. glauca } & 1988 & $6 \mathrm{VI}$ & 20,9 & 436 & $13-16 \mathrm{VI}$ & 13,9 & 552 & $18 \mathrm{VII}$ & 23,2 & 1164 \\
\hline & 1989 & $13 \mathrm{~V}$ & 11,5 & 254 & $30 \mathrm{~V}-2 \mathrm{VI}$ & 13,8 & 492 & $2 \mathrm{VIII}$ & 21,2 & 1554 \\
\hline & 1990 & $4 \mathrm{VI}$ & 14,6 & 284 & 29-31 VI & 8,9 & 259 & $18 \mathrm{VII}$ & 14,4 & 384 \\
\hline \multirow{2}{*}{ P. mariana } & 1988 & $9 \mathrm{VI}$ & 11,5 & 471 & $17-19 \mathrm{VI}$ & 17,8 & 599 & $18 \mathrm{VII}$ & 23,2 & 1164 \\
\hline & 1990 & $7 \mathrm{VI}$ & 6,3 & 300 & $10-14 \mathrm{VI}$ & 8,3 & 346 & $25 \mathrm{VI}$ & 16,8 & 450 \\
\hline \multirow{3}{*}{ P. obovata } & 1988 & $6 \mathrm{VI}$ & 20,9 & 436 & $13-16 \mathrm{VI}$ & 13,9 & 552 & $22 \mathrm{VII}$ & 23,2 & 1249 \\
\hline & 1989 & $19 \mathrm{~V}$ & 10,0 & 323 & $23-29 \mathrm{~V}$ & 13,8 & 444 & $25 \mathrm{VII}$ & 15,0 & 1398 \\
\hline & 1990 & $4 \mathrm{VI}$ & 17,2 & 292 & 10-14 VI & 8,3 & 346 & $2 \mathrm{VII}$ & 10,6 & 522 \\
\hline \multirow{3}{*}{ P. abies } & 1988 & $3 \mathrm{VI}$ & 8,0 & 381 & $20-23 \mathrm{VI}$ & 21,7 & 673 & $22 \mathrm{VII}$ & 20,4 & 1249 \\
\hline & 1989 & $13 \mathrm{~V}$ & 11,5 & 254 & $3-5 \mathrm{VI}$ & 13,8 & 543 & $2 \mathrm{VIII}$ & 21,2 & 1556 \\
\hline & 1990 & $1 \mathrm{VI}$ & 7,6 & 268 & 4-6 VI & 12,5 & 298 & $25 \mathrm{VI}$ & 14,2 & 450 \\
\hline
\end{tabular}

Установлено, что время кульминации прироста хвои также довольно существенно изменяется по годам. Раньше всего эта фаза наступает у $P$. obovata и $P$. glauca $(23 \mathrm{~V}-31$ VI), а позже всего - у P. pungens (13 VI - 1 VII). Величина максимального прироста у разных видов ели также варьирует в широких пределах (табл. 5). Его наибольшая величина (в среднем 1,2-1,6 мм/сут) обнаружена у $P$. pungens и $P$. abies. У других изучаемых видов этот показатель в 2-3 раза меньше. Следует подчеркнуть, что погодичная изменчивость величины максимального прироста хвои у этих видов может достигать 50-300 \% (табл. 5).

Оказалось, что сроки прекращения роста хвои у разных видов, как и его начала, различаются на 3-22 сут и заметно варьируют по годам. При этом погодичная разница в сроках у отдельных видов рода Picea может составлять от 3 сут до 5 недель, что согласуется с результатами, полученными ранее С. А. Потаповой (1983).

Погодичные изменения в сроках начала и окончания роста хвои вызывают изменения и в продолжительности ее формирования, которая может меняться в 1,5-5 раз (табл. 5). Наиболее продолжительный рост характерен для P. abies (25-81 сут), а самый короткий для P. mariana (18-36 сут).

Обнаруженная значительная изменчивость в продолжительности и интенсивности роста хвои обусловливает и соответствующие различия в величине ее годичного прироста. Длина хвои у $P$. obovata при этом может различаться в 1,5 раза, а у других видов - не боль- 
Таблица 5. Основные характеристики линейного прироста хвои у различных видов рода Picea Table 5. The main characteristics of the length growth of needles in different Picea species

\begin{tabular}{|l|c|c|c|c|}
\hline \multirow{2}{*}{ Виды } & $\begin{array}{c}\text { Годы } \\
\text { наблюдений }\end{array}$ & $\begin{array}{c}\text { Максимальный } \\
\text { суточный прирост, мм }\end{array}$ & $\begin{array}{c}\text { Годичный прирост, } \\
\text { мм }\end{array}$ & $\begin{array}{c}\text { Продолжительность } \\
\text { роста, сут. }\end{array}$ \\
\hline \multirow{3}{*}{ P. pungens } & 1988 & $1,2 \pm 0,05$ & $23 \pm 1$ & $45 \pm 2$ \\
& 1989 & $0,8 \pm 0,03$ & $30 \pm 2$ & $78 \pm 3$ \\
& 1990 & $1,7 \pm 0,06$ & $22 \pm 1$ & $15 \pm 1$ \\
\hline \multirow{3}{*}{ Plauca } & 1988 & $0,4 \pm 0,02$ & $20 \pm 1$ & $42 \pm 2$ \\
& 1989 & $0,4 \pm 0,02$ & $24 \pm 1$ & $81 \pm 3$ \\
\hline \multirow{3}{*}{ P. mariana } & 1990 & $0,4 \pm 0,02$ & $18 \pm 1$ & $36 \pm 2$ \\
\hline obovata & 1988 & $0,3 \pm 0,01$ & $16 \pm 1$ & $18 \pm 1$ \\
\hline P. abies & 1990 & $1,1 \pm 0,05$ & $15 \pm 1$ & $46 \pm 2$ \\
& 1988 & $0,3 \pm 0,01$ & $14 \pm 1$ & $67 \pm 3$ \\
& 1989 & $0,6 \pm 0,03$ & $11 \pm 1$ & $28 \pm 1$ \\
\hline
\end{tabular}

ше чем на 15-30 \%. Из данных табл. 5 следует, что наиболее длинная хвоя (в среднем за 3 года 25,1 мм) формируется у P. pungens. У $P$. abies и $P$. glauca eе размеры несколько меньше (20-22 мм), а у P. mariana и P. obovata они составляют всего 14-15 мм. Длина хвои у $P$. pungens больше, чем у P. obovata, в среднем почти в 2 раза. При этом скорость роста хвои у первого вида в 2-3 раза выше, чем у второго, а продолжительность их роста примерно одинакова (Кищенко, 1998).

По данным 3-летних наблюдений, начало роста хвои при самой низкой среднесуточной температуре воздуха $\left(6,3-11,5^{\circ} \mathrm{C}\right)$ отмечается у $P$. abies и $P$. mariana (табл. 4). У остальных видов этот процесс начинается при 10,0-20,9 ${ }^{\circ} \mathrm{C}$. Значительная изменчивость температуры воздуха (на 5-11 ${ }^{\circ} \mathrm{C}$ ) во время начала роста хвои позволяет предположить отсутствие строго определенной связи этой фенофазы с данным фактором. Различия между видами по их требовательности к данному фактору в этот момент просматриваются с достаточной очевидностью. Влияние температуры воздуха на сроки наступления данной фенофазы у видов рода Picea отмечено и другими исследователями (Фролова, 1979; Шкутко, 1991).

Исследованиями установлено, что показатель теплообеспеченности для начала роста хвои гораздо более стабилен, чем текущая температура воздуха. Выяснилось, что рост хвои $P$. abies начинается при сумме положительных температур $254-381{ }^{\circ} \mathrm{C}$, а у интродуцированных видов - при 254-471 ㄷ․ Подобная зависимость обнаружена и Л.А.Фроловой (1979).

Обнаружено, что в период кульминации прироста хвои температура воздуха и теплообеспеченность могут изменяться в 1,5-2 раза. Такая значительная вариация температурного режима указывает на отсутствие явного влияния данных параметров на кульминацию прироста хвои у всех изучаемых видов рода Picea (Кищенко, 1998а).

Во время прекращения роста хвои среднесуточная температура воздуха и сумма по- 
ложительных температур варьируют в широких пределах - соответственно 10,6-23,2 и 384-1556 ${ }^{\circ} \mathrm{C}$. Эти данные показывают, что сроки прекращения роста хвои у представителей рода Picea не связаны с температурным режимом, а скорее всего обусловлены генотипом вида. По данным Л.А. Фроловой (1979), для всех интродуцентов рода Picea тепла вполне достаточно для завершения годичного цикла развития вегетативных почек.

Самым приспособленным к местным экологическим условиям из изучаемых видов является аборигенный вид P. abies, который наиболее адекватно реагирует на изменчивость факторов среды. Проведение корреляционного анализа позволило обнаружить прямую и довольно тесную связь $(\mathrm{r}=+0,7-+0,9 ; \mathrm{p}<0,05)$ между динамикой прироста хвои P. abies и аналогичным показателем P. glauca. В отношении P. mariana искомая зависимость почти в 2 раза слабее. Достоверная корреляция между динамикой прироста хвои аборигенного и остальных изучаемых видов рода Picea не обнаружена. Следовательно, можно предположить, что ростовые реакции у этих видов интродуцентов весьма сильно отличаются от таковых у аборигенного вида.

Дисперсионный анализ установил силу влияния некоторых экологических факторов на динамику прироста хвои изучаемых видов рода Picea. Выяснилось, что степень этого влияния может весьма заметно изменяться по годам в зависимости от биологических особенностей вида. Например, температура воздуха обеспечивает изменчивость прироста хвои у $P$. pungens до $34 \%$, а у P. abies до $96 \%$. Влажность воздуха может почти полностью определить интенсивность роста хвои у этих видов. Наоборот, формирование хвои у $P$. obovata определяется данным фактором всего на 3-4 \%. Атмосферные осад- ки почти не влияют на рост хвои $P$. obovata и P. mariana, а у других видов рода Picea иногда обеспечивают почти 50 \% изменчивости ее прироста.

\section{Развитие растений}

Анализ данных статистической обработки наблюдений показал, что ошибка средней многолетней величины фенодат изучаемых видов рода Picea весьма незначительна и, как правило, не превышает 1-2 сут (табл. 6). Лишь для фаз окончания линейного роста побегов и обособления почек ее величина возрастает до 4-5 сут. Наибольшая вариабельность фенодат характерна также для этих двух фенофаз: среднеквадратическое отклонение составляет от 14 до 20 сут. Для остальных фенофаз его величина обычно значительно меньше (4-8 сут). Изучая рост различных видов рода Picea, многие авторы обнаружили, что погодичная изменчивость сроков начала тех или иных фенофаз может варьировать от нескольких суток (Иваненко, 1962) до 1-2 недель (Фролова, 1979; Luomajoki, 1977) или даже до 1 месяца (Шкутко и др., 1974).

Проведенные исследования свидетельствуют о том, что ритмика сезонного развития изучаемых видов имеет свои специфические особенности (Кищенко, 2000). По среднемноголетним данным, первыми (11-15 V) начинают набухать почки у $P$. abies, $P$. obovata, $P$. glauca и P. pungens. У P. mariana эта фенофаза отмечается на 2-6 сут позже (табл. 6).

Линейный рост побегов начинается через 2-3 недели, при этом отмеченные различия между видами сохраняются. Дольше всего (до 2 VIII) растут побеги у P. obovata. Завершение этого процесса у других видов наблюдается на 3-7 сут раньше. Опробковение оснований побегов у исследуемых видов начинается почти в одно время - 16-21 VII. Раньше всего процесс опробковения побегов 
Таблица 6. Среднемноголетние даты наступления фенофаз у различных видов рода Picea

Table 6. Average long-term dates of the onset of phenophases in different Picea species

\begin{tabular}{|c|c|c|c|c|c|c|}
\hline \multicolumn{2}{|l|}{ Фенофазы и стат. показатели } & P. pungens & P. glauca & P. mariana & P. obovata & P. abies \\
\hline \multirow[t]{2}{*}{ Набухание вегетативных почек } & $\mathrm{M} \pm \mathrm{m}_{\mathrm{M}}$ & $12 \mathrm{~V} \pm 1,5$ & $11 \mathrm{~V} \pm 1,5$ & $17 \mathrm{~V} \pm 1,5$ & $15 \mathrm{~V} \pm 7,1$ & $15 \mathrm{~V} \pm 7,3$ \\
\hline & $\sigma$ & 10,0 & 6,7 & 5,7 & 6,5 & 7,3 \\
\hline \multirow[t]{2}{*}{ Разверзание вегетативных почек } & $\mathrm{M} \pm \mathrm{m}_{\mathrm{M}}$ & $8 \mathrm{VI} \pm 1,6$ & $2 \mathrm{VI} \pm 1,8$ & $31 \mathrm{~V} \pm 1,6$ & $28 \mathrm{~V} \pm 1,4$ & $25 \mathrm{~V} \pm 2,0$ \\
\hline & $\sigma$ & 6,2 & 6,8 & 5,4 & 5,2 & 7,9 \\
\hline \multirow[t]{2}{*}{ Начало линейного роста побегов } & $\mathrm{M} \pm \mathrm{m}_{\mathrm{M}}$ & $4 \mathrm{VI} \pm 2,9$ & $2 \mathrm{VI} \pm 1,8$ & $31 \mathrm{~V} \pm 1,5$ & $28 \mathrm{~V} \pm 1,4$ & $25 \mathrm{~V} \pm 2,0$ \\
\hline & $\sigma$ & 11,2 & 6,8 & 6,2 & 5,2 & 7,9 \\
\hline \multirow{2}{*}{$\begin{array}{l}\text { Окончание линейного роста } \\
\text { побегов }\end{array}$} & $\mathrm{M} \pm \mathrm{m}_{\mathrm{M}}$ & $29 \mathrm{VII} \pm 4,5$ & $26 \mathrm{VII} \pm 3,6$ & $30 \mathrm{VII} \pm 5,4$ & $2 \mathrm{VIII} \pm 3,8$ & $27 \mathrm{VII} \pm 5,0$ \\
\hline & $\sigma$ & 17,5 & 14,2 & 20,0 & 13,8 & 19,4 \\
\hline \multirow[t]{2}{*}{ Опробковение оснований побегов } & $\mathrm{M} \pm \mathrm{m}_{\mathrm{M}}$ & $16 \mathrm{VII} \pm 1,0$ & $18 \mathrm{VII} \pm 0,8$ & $21 \mathrm{VII} \pm 0,8$ & $20 \mathrm{VII} \pm 2,1$ & $19 \mathrm{VII} \pm 0,6$ \\
\hline & $\sigma$ & 3,8 & 3,2 & 3,7 & 7,9 & 2,3 \\
\hline \multirow{2}{*}{$\begin{array}{l}\text { Опробковение ростовых побегов } \\
\text { по всей длине }\end{array}$} & $\mathrm{M} \pm \mathrm{m}_{\mathrm{M}}$ & $18 \mathrm{VIII} \pm 1,7$ & $19 \mathrm{VIII} \pm 1,3$ & $21 \mathrm{VIII} \pm 1,5$ & $24 \mathrm{VIII} \pm 1,0$ & $11 \mathrm{VIII} \pm 5,0$ \\
\hline & $\sigma$ & 6,6 & 2,9 & 5,6 & 3,8 & 19,3 \\
\hline \multirow[t]{2}{*}{ Обособление хвои на побегах } & $\mathrm{M} \pm \mathrm{m}_{\mathrm{M}}$ & $12 \mathrm{VI} \pm 1,5$ & $10 \mathrm{VI} \pm 2,1$ & $5 \mathrm{VI} \pm 2,0$ & $6 \mathrm{VI} \pm 1,5$ & $3 \mathrm{VI} \pm 1,4$ \\
\hline & $\sigma$ & 5,6 & 8,2 & 7,3 & 5,4 & 5,4 \\
\hline \multirow{2}{*}{$\begin{array}{l}\text { Завершение роста и вызревание } \\
\text { хвои }\end{array}$} & $\mathrm{M} \pm \mathrm{m}_{\mathrm{M}}$ & $21 \mathrm{VI} \pm 1,6$ & $17 \mathrm{VI} \pm 1,6$ & $14 \mathrm{VI} \pm 2,4$ & $14 \mathrm{VI} \pm 1,6$ & $13 \mathrm{VI} \pm 6,4$ \\
\hline & $\sigma$ & 6,3 & 6,3 & 8,9 & 6,1 & 6,1 \\
\hline \multirow[t]{2}{*}{ Расцвечивание отмирающей хвои } & $\mathrm{M} \pm \mathrm{m}_{\mathrm{M}}$ & $6 \mathrm{X} \pm 3,1$ & $11 \mathrm{X} \pm 4,9$ & $23 \mathrm{X} \pm 0,9$ & $24 \mathrm{X} \pm 4,8$ & $24 \mathrm{X} \pm 1,0$ \\
\hline & $\sigma$ & 12,0 & 18,8 & 3,4 & 4,5 & 3,8 \\
\hline \multirow[t]{2}{*}{ Опадение хвои } & $\mathrm{M} \pm \mathrm{m}_{\mathrm{M}}$ & $16 \mathrm{X} \pm 2,6$ & $20 \mathrm{X} \pm 3,2$ & $5 \mathrm{XI} \pm 0,8$ & $16 \mathrm{XI} \pm 1,2$ & $15 \mathrm{XI} \pm 2,6$ \\
\hline & $\sigma$ & 10,1 & 12,5 & 3,1 & 4,6 & 9,4 \\
\hline \multirow{2}{*}{$\begin{array}{l}\text { Обособление на побегах } \\
\text { почек }\end{array}$} & $\mathrm{M} \pm \mathrm{m}_{\mathrm{M}}$ & $25 \mathrm{VII} \pm 4,7$ & $26 \mathrm{VII} \pm 4,6$ & $25 \mathrm{VII} \pm 4,1$ & $28 \mathrm{VII} \pm 5,0$ & $29 \mathrm{VII} \pm 5,4$ \\
\hline & $\sigma$ & 18,4 & 17,8 & 15,5 & 18,7 & 20,08 \\
\hline
\end{tabular}

Примечание: М - среднеарифметическая величина; $\mathrm{m}_{\mathrm{M}}$ - ошибка среднеарифметической величины; $\sigma$ среднеквадратическое отклонение.

по всей длине завершается у P. abies (в среднем за 28 лет 11 VIII), а позже всего (24 VIII) y $P$. obovata.

Обособление вегетативных почек у изучаемых видов рода Picea происходит почти одновременно - 25-29 VII. Л. А. Фролова (1979) ранее также пришла к выводу о том, что у большинства интродуцированных видов рода Picea различия в требовательности к температурному фактору проявляются лишь в начале вегетации, а в дальнейшем они почти исчезают.

В фазу разверзания почек раньше всего (25-28 V) вступают P. abies и $P$. obovata, а позже всего (8 VI) - P. pungens. Обособление хвои у евроазиатских видов происходит уже 3-6 VI, а у североамериканских - на 4-6 сут позже. Наиболее рано рост хвои заканчивается (13-14 VI) у P. mariana, $P$. abies и $P$. obovata, а у остальных видов - на 3-7 сут позже. Самой первой $(6 \mathrm{X})$ в фазу расцвечивания хвои вступает $P$. pungens, а последними (23-24 X) евроазиатские виды. Дольше всего (до 15-16 XI) отмирающая хвоя держится у P. abies и P. obovata. У остальных видов рода Picea она начинает опадать уже 16 X-5 XI.

Проведенные исследования показали, что фазы начала, обособления и завершения 
роста хвои у аборигенного вида начинаются на 2-10 сут раньше, а фазы расцвечивания и опадения хвои - на 10-30 сут позже, чем у интродуцентов. Очередность наступления фенофаз у изучаемых видов из года в год не меняется (Кищенко, 1995). Этот вывод согласуется с мнением Н.В. Трулевич (1991). Наибольшая стабильность в сроках наступления фенофаз при этом характерна для аборигенного вида. Все изученные виды растений успевают закончить вегетацию к наступлению зимнего периода, и их цикл вегетативного развития соответствует вегетационному периоду места интродукции. Этот вывод полностью согласуется с результатами исследований О.А. Гончаровой с соавторами (2015), проведенных на Кольском полуострове.

При анализе состояния среды во время начала тех или иных фенофаз обнаружена весьма значительная погодичная вариабель- ность значений относительной влажности воздуха, атмосферных осадков и суммарной солнечной радиации. Между тем температурный режим в момент вступления растения в очередную фенофазу довольно стабилен, что указывает на существенное влияние данного фактора. Так, набухание почек при самой высокой среднесуточной температуре воздуха (около $10{ }^{\circ} \mathrm{C}$ ) и наибольшей сумме положительных температур (220-231 $\left.{ }^{\circ} \mathrm{C}\right)$ начинается у P. mariana и P. abies (табл. 7). Для других видов ели величины этих параметров среды намного ниже (соответственно 7,3-8,3 и $\left.165-193{ }^{\circ} \mathrm{C}\right)$.

Разверзание почек у $P$. abies и $P$. pungens происходит при повышении температуры до $12,1-13,1^{\circ} \mathrm{C}$, а суммы положительных температур - до $386-452{ }^{\circ} \mathrm{C}$. У остальных видов ели эта фенофаза начинается при более прохладной погоде $\left(10,0-11,0\right.$ и $\left.301-380{ }^{\circ} \mathrm{C}\right)$. Сле-

Таблица 7. Среднесуточные значения экологических факторов во время прохождения фенофаз у различных видов рода Picea

Table 7. Daily average values of environmental factors during different phenophases of various Picea species

\begin{tabular}{|c|c|c|c|c|c|c|}
\hline \multirow{2}{*}{\multicolumn{2}{|c|}{ Фенофазы и факторы }} & \multicolumn{5}{|c|}{ Виды } \\
\hline & & \multirow{2}{*}{$\frac{P . \text { pungens }}{3}$} & \multirow{2}{*}{$\frac{P . \text { glauca }}{4}$} & \multirow{2}{*}{$\frac{\text { P. mariana }}{5}$} & \multirow{2}{*}{$\frac{\text { P. obovata }}{6}$} & \multirow{2}{*}{$\frac{\text { P. abies }}{7}$} \\
\hline 1 & 2 & & & & & \\
\hline \multirow[t]{5}{*}{ Набухание вегетативных почек } & $\mathrm{T}$ & 8,1 & 7,3 & 10,4 & 8,3 & 10,2 \\
\hline & СПТ & 177 & 165 & 220 & 193 & 231 \\
\hline & B & 65 & 69 & 57 & 67 & 66 \\
\hline & $\mathrm{O}$ & 1,0 & 4,1 & 1,6 & 2,2 & 1,9 \\
\hline & $\mathrm{P}$ & 383 & 397 & 370 & 380 & 397 \\
\hline \multirow[t]{5}{*}{ Разверзание вегетативных почек } & $\mathrm{T}$ & 12,1 & 11,0 & 10,7 & 10,0 & 13,1 \\
\hline & СПТ & 452 & 380 & 360 & 301 & 386 \\
\hline & B & 73 & 65 & 73 & 71 & 69 \\
\hline & $\mathrm{O}$ & 3,3 & 1,9 & 2,0 & 1,4 & 2,2 \\
\hline & $\mathrm{P}$ & 423 & 430 & 396 & 416 & 411 \\
\hline \multirow[t]{5}{*}{ Начало линейного роста побегов } & $\mathrm{T}$ & 11,7 & 10,7 & 10,9 & 10,1 & 10,9 \\
\hline & СПТ & 440 & 376 & 360 & 303 & 391 \\
\hline & B & 70 & 66 & 73 & 72 & 66 \\
\hline & $\mathrm{O}$ & 1,4 & 1,6 & 2,0 & 1,4 & 1,6 \\
\hline & $\mathrm{P}$ & 445 & 432 & 407 & 415 & 506 \\
\hline
\end{tabular}


Продолжение таблицы 7

Continued Table. 7

\begin{tabular}{|c|c|c|c|c|c|c|}
\hline 1 & 2 & 3 & 4 & 5 & 6 & 7 \\
\hline $\begin{array}{l}\text { Окончание линейного роста } \\
\text { побегов }\end{array}$ & $\begin{array}{c}\mathrm{T} \\
\mathrm{C} \Pi \mathrm{T} \\
\mathrm{B} \\
\mathrm{O} \\
\mathrm{P}\end{array}$ & $\begin{array}{c}15,2 \\
1208 \\
78 \\
1,3 \\
356\end{array}$ & $\begin{array}{c}16,2 \\
1173 \\
75 \\
0,7 \\
369\end{array}$ & $\begin{array}{c}14,2 \\
1229 \\
77 \\
10,2 \\
380\end{array}$ & $\begin{array}{c}16,0 \\
1178 \\
77 \\
0,7 \\
419\end{array}$ & $\begin{array}{c}17,0 \\
1152 \\
72 \\
0,5 \\
431\end{array}$ \\
\hline Опробковение основания побегов & $\begin{array}{c}\mathrm{T} \\
\mathrm{C \Pi T} \\
\mathrm{B} \\
\mathrm{O} \\
\mathrm{P}\end{array}$ & $\begin{array}{c}16,9 \\
1022 \\
77 \\
4,5 \\
428\end{array}$ & $\begin{array}{c}16,3 \\
1018 \\
80 \\
1,6 \\
380\end{array}$ & $\begin{array}{c}15,8 \\
1113 \\
80 \\
3,2 \\
424\end{array}$ & $\begin{array}{c}15,9 \\
1058 \\
79 \\
1,0 \\
412\end{array}$ & $\begin{array}{c}15,9 \\
1085 \\
77 \\
1,7 \\
456\end{array}$ \\
\hline $\begin{array}{l}\text { Опробковение побегов по всей } \\
\text { длине }\end{array}$ & $\begin{array}{c}\mathrm{T} \\
\mathrm{C \Pi T} \\
\mathrm{B} \\
\mathrm{O} \\
\mathrm{P}\end{array}$ & $\begin{array}{c}13,9 \\
1518 \\
82 \\
2,2 \\
344\end{array}$ & $\begin{array}{c}12,2 \\
1536 \\
86 \\
5,8 \\
216\end{array}$ & $\begin{array}{c}12,7 \\
1585 \\
84 \\
1,9 \\
266\end{array}$ & $\begin{array}{c}12,6 \\
1429 \\
81 \\
1,9 \\
181\end{array}$ & $\begin{array}{c}10,6 \\
1564 \\
86 \\
5,2 \\
205\end{array}$ \\
\hline Обособление хвои на побегах & $\begin{array}{c}\mathrm{T} \\
\mathrm{C} \Pi \mathrm{T} \\
\mathrm{B} \\
\mathrm{O} \\
\mathrm{P}\end{array}$ & $\begin{array}{c}12,4 \\
511 \\
69 \\
1,6 \\
389\end{array}$ & $\begin{array}{c}13,2 \\
474 \\
73 \\
1,6 \\
407\end{array}$ & $\begin{array}{c}12,9 \\
433 \\
65 \\
1,3 \\
452\end{array}$ & $\begin{array}{c}11,9 \\
402 \\
67 \\
1,6 \\
470\end{array}$ & $\begin{array}{c}14,3 \\
426 \\
72 \\
2,5 \\
353\end{array}$ \\
\hline $\begin{array}{l}\text { Завершение роста и вызревание } \\
\text { хвои }\end{array}$ & $\begin{array}{c}\mathrm{T} \\
\mathrm{C \Pi T} \\
\mathrm{B} \\
\mathrm{O} \\
\mathrm{P}\end{array}$ & $\begin{array}{c}14,2 \\
622 \\
69 \\
1,0 \\
477\end{array}$ & $\begin{array}{c}14,3 \\
574 \\
70 \\
0,8 \\
439\end{array}$ & $\begin{array}{c}13,6 \\
538 \\
72 \\
2,2 \\
452\end{array}$ & $\begin{array}{c}13,0 \\
529 \\
70 \\
1,0 \\
396\end{array}$ & $\begin{array}{c}15,3 \\
573 \\
75 \\
2,2 \\
341\end{array}$ \\
\hline Расцвечивание отмирающей хвои & $\begin{array}{c}\mathrm{T} \\
\mathrm{C \Pi T} \\
\mathrm{B} \\
\mathrm{O} \\
\mathrm{P}\end{array}$ & $\begin{array}{c}4,4 \\
1920 \\
84 \\
8,7 \\
2727\end{array}$ & $\begin{array}{c}3,4 \\
1903 \\
83 \\
9,0 \\
2125\end{array}$ & $\begin{array}{c}3,4 \\
1952 \\
83 \\
8,4 \\
1948\end{array}$ & $\begin{array}{c}3,0 \\
1952 \\
83 \\
8,4 \\
2152\end{array}$ & $\begin{array}{c}3,4 \\
1952 \\
83 \\
8,4 \\
1948\end{array}$ \\
\hline Опадение хвои & $\begin{array}{c}\mathrm{T} \\
\mathrm{C} \Pi \mathrm{T} \\
\mathrm{B} \\
\mathrm{O} \\
\mathrm{P}\end{array}$ & $\begin{array}{c}3,7 \\
1950 \\
83 \\
10,2 \\
2152\end{array}$ & $\begin{array}{c}3,7 \\
1957 \\
83 \\
10,2 \\
2152\end{array}$ & $\begin{array}{c}3,0 \\
2100 \\
89 \\
8,2 \\
1927\end{array}$ & $\begin{array}{c}1,5 \\
1917 \\
88 \\
8,0 \\
2070\end{array}$ & $\begin{array}{c}2,4 \\
1883 \\
82 \\
5,0 \\
2262\end{array}$ \\
\hline Обособление на побегах почек & $\begin{array}{c}\mathrm{T} \\
\mathrm{C \Pi T} \\
\mathrm{B} \\
\mathrm{O} \\
\mathrm{P}\end{array}$ & $\begin{array}{c}15,0 \\
1152 \\
77 \\
1,7 \\
463\end{array}$ & $\begin{array}{c}16,6 \\
1162 \\
75 \\
3,9 \\
394\end{array}$ & $\begin{array}{c}16,9 \\
1171 \\
76 \\
1,3 \\
393\end{array}$ & $\begin{array}{c}15,8 \\
1200 \\
75 \\
1,2 \\
381\end{array}$ & $\begin{array}{c}15,8 \\
1155 \\
76 \\
2,5 \\
322\end{array}$ \\
\hline
\end{tabular}

Примечание: Т - температура воздуха, ${ }^{\circ} \mathrm{C}$; СПТ - сумма положительных температур, ${ }^{\circ} \mathrm{C} ; \mathrm{B}$ - относительная влажность воздуха,\%; О - атмосферные осадки, мм; Р - солнечная радиация, кал/см². 
дует отметить, что начало этих двух важнейших фенофаз у тех же самых видов в условиях Главного Ботанического сада РАН происходит при гораздо меньшей теплообеспеченности (Фролова, 1979). Линейный рост побегов у всех исследуемых видов ели начинается при очень близких значениях температуры воздуха - 10,1-11,7 ${ }^{\circ} \mathrm{C}$. Однако требовательность к количеству тепла для начала данной фенофазы у $P$. abies, $P$. obovata и $P$. glauca значительно ниже (около $303-391{ }^{\circ} \mathrm{C}$ ), чем у других видов (360-440 $\left.{ }^{\circ} \mathrm{C}\right)$.

Выяснилось, что степень влияния экологических условий на развитие видов рода Picea в значительной мере определяется их биологическими особенностями и периодом воздействия фактора.

Температура воздуха наиболее сильное влияние (28-43 \%) оказывает на сроки начала набухания почек. Подобная зависимость не обнаружена только для P. mariana. Степень влияния данного фактора на разверзание почек у североамериканских видов P. pungens и P. glauca снижается до 25-37 \%, а у других видов оно почти не прослеживается. Прекращение роста побегов в незначительной мере (9-33 \%) зависит от температурного режима. В фазе опробковения побегов по всей длине только P. pungens испытывает сильное воздействие (34\%) температуры. У других видов рода Picea эта зависимость очень слаба либо вовсе отсутствует.

Достоверное влияние температуры на сроки обособления хвои установлено для P. mariana и P. obovata (19-29 \%). Гораздо слабее этот фактор отражается на сроках завершения роста хвои (10-22\%), ее расцвечивания (25-30 \%) и обособления почек (7-12\%). Л.А. Фролова (1979) пришла к выводу, что в условиях Подмосковья интродуцированные виды рода Picea получают достаточное количество тепла для завершения вегетации.
На развитии растений заметно сказывается и относительная влажность воздуха. Степень влияния этого фактора на фазу набухания почек достигает 24-48 \%. Окончание роста побегов связано с ним довольно слабо (4-25 \%). Однако на фазы опробковения оснований побегов, роста и опадения хвои влажность воздуха влияет иногда довольно заметно (16-48 \%). Сроки обособления почек довольно слабо зависят от данного фактора (4-15\%).

Степень влияния атмосферных осадков на время прохождения тех или иных фенофаз в значительной мере обусловлена биологическими особенностями вида, достигая 10-40 \%. Для части изучаемых видов в некоторые периоды развития такое влияние вовсе отсутствует (Кищенко, 1995).

Величина суммарной солнечной радиации существенно сказывается на ходе вегетативного развития растений. Данный фактор заметно влияет на сроки набухания вегетативных почек у $P$. obovata, $P$. glauca и P. mariana (25-30 \%). У всех изучаемых видов обнаружена существенная зависимость фазы разверзания почек от этого фактора. Прекращение роста побегов связано с интенсивностью солнечной радиации у всех видов (31-93 \%), за исключением P. abies. На сроках опробковения побегов по всей длине у P. glauca, P. mariana и P. abies влияние этого параметра сказывается довольно заметно (10-41 \%). Определенное влияние (13-19\%) оказывает солнечный свет на сроки наступления фазы обособления хвои у всех видов, кроме $P$. glauca. Завершение роста хвои не связано с данным фактором только у P. abies и $P$. obovata. У двух других изучаемых видов рода Picea (P. pungens и P. glauca) прослеживается существенное влияние (24-29\%) этого фактора на сроки расцвечивания хвои. Из всех регистрируемых факторов на сроки 
обособления почек наиболее сильно влияет солнечная радиация.

Проведенными ранее исследованиями (Гурский, 1957; Ворошилов, 1960; Шкутко, 1973) установлено, что погодные условия периода заложения зимующих почек могут заметно сказаться на развитии побегов в следующем году. Полученные данные свидетельствуют о существенной и достоверной положительной корреляции между фенодатами большинства изучаемых видов рода Picea и температурой воздуха этого периода ( $\mathrm{r}=+0,5-+0,9 ; \mathrm{p}<0,05)$. Исключением является фаза расцвечивания хвои, для которой обнаруженная связь носит отрицательный характер. Сроки опробковения побегов от температуры воздуха, как правило, не зависят. Существенное влияние на развитие растений оказывает и влажность воздуха периода заложения почек ( $\mathrm{r}=+0,3-+0,9$; $\mathrm{p}<0,05)$. Такая зависимость не прослеживается лишь в фазе опробковения побегов. Заметная корреляция количества осадков этого периода отмечена со следующими фенофазами: положительная - с окончанием роста побегов, расцвечиванием хвои и обособлением почек; отрицательная - с опадением хвои. Солнечная радиация периода заложения почек существенно влияет на сроки наступления всех фе- нофаз, за исключением опробковения побегов, расцвечивания и опадения хвои.

\section{Перспективность интродукции}

Перспективность интродуцкции растений оценивали в баллах по методике П. И. Лапина и С. В. Сидневой (1973). Исследованиями установлено, что по пяти показателям оценки интродукции различия между видами незначительны (табл. 8). У всех видов отмечены высокие степень вызревания побегов (18-20 баллов из 20 возможных), зимостойкость (2225 баллов из 25 возможных), сохранение габитуса (8-10 баллов из 10 возможных), побегообразовательная способность (4-5 баллов из 5 возможных) и регулярность прироста осевых побегов (4-5 баллов из 5 возможных).

Самые большие различия в оценочных баллах между видами имеют место по показателям, связанным с развитием репродуктивной сферы. Так, максимальная способность к генеративному развитию отмечена у P. glauca и P. pungens - 20 баллов (табл. 8). У других видов развитие генеративных органов вообще не происходит.

Возможность размножения интродуцентов в культуре оценивается максимум пятью баллами, что не заслуживает ни один из из-

Таблица 8. Оценка перспективности интродукции видов семейства Picea, баллы

Table 8. Assessment of the prospects for the introduction of Picea species (scores)

\begin{tabular}{|c|c|c|c|c|c|c|c|c|}
\hline Виды & 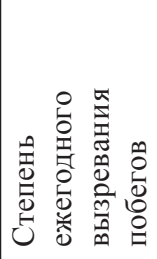 & 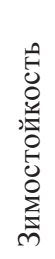 & 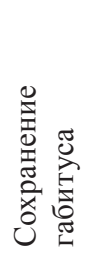 & 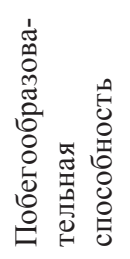 & 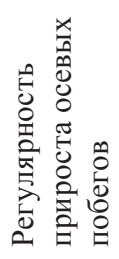 & 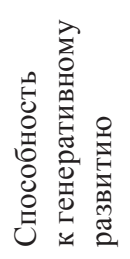 & 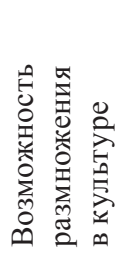 & 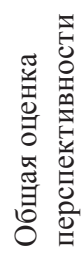 \\
\hline P. glauca & 20 & 25 & 10 & 5 & 5 & 20 & 3 & 88 \\
\hline P. pungens & 20 & 25 & 10 & 5 & 5 & 20 & 3 & 88 \\
\hline P. obovata & 20 & 25 & 10 & 5 & 5 & 0 & 0 & 65 \\
\hline P. mariana & 18 & 22 & 8 & 4 & 4 & 0 & 0 & 56 \\
\hline
\end{tabular}


учаемых видов. Эта способность у $P$. glauca u P. pungens оценивается в 3 балла, у остальных видов - в 0 баллов.

На основании вышеприведенных данных получена общая оценка перспективности изучаемых интродуцентов. Выяснилось, что к очень перспективным относятся $P$. glauca и P. pungens (88 баллов), к довольно перспективным - P. obovata (65 баллов), к перспективным - P. mariana (56 баллов). К аналогичному выводу в отношении данных видов интродуцентов ранее пришли в Центральной России С. М. Лазарева (2014), Р. А. Воробьев и Д. Н. Тебенькова (2013), в Архангельской области О.С. Залывская (2014), на Европейском Северо-востоке России Н. В. Паутова (2011).

\section{Заключение}

Рост и развитие видов Picea в условиях интродукции имеет свои особенности. Обнаружено, что рост побегов у $P$. abies начинается на 1-4 недели раньше, а заканчивается на 1-3 недели позже, чем у интродуцентов. Ранее всего кульминация прироста побегов происходит у $P$. glauca и $P$. obovata, а позже всего - у P. abies. Наибольшая величина их прироста характерна для P. abies, а у других видов она в 1,5-2 раза меньше. Сроки начала кульминации и окончания роста побегов под влиянием экологических факторов весьма заметно варьируют по годам.

Наиболее длинные побеги формируются у P. abies. Различия в величине данного показателя обусловливаются в основном интенсивностью, а не продолжительностью роста побегов. Динамика прироста побегов у интродуцентов весьма заметно отличается от таковой у аборигенного вида. Начало ро- ста побегов и кульминация их прироста у изучаемых видов в определенной мере зависят от температурного режима воздуха. Влажность воздуха значительно превышает норму, необходимую для роста побегов у интродуцированных видов рода Picea.

Рост хвои у $P$. abies начинается на 1-2 недели раньше, чем у интродуцированных видов. Ранее всего кульминация ее прироста происходит у $P$. obovata и $P$. glauca, а позже всего - у P. pungens. Наибольшая величина прироста хвои характерна для P. abies и P. pungens, у других видов она в 2-4 раза меньше. Сроки начала, кульминации и окончания роста хвои под влиянием экологических факторов из года в год очень варьируют.

Наиболее длинная хвоя формируется у P. pungens и P. abies. Величина данного показателя обусловливается в основном интенсивностью, а не продолжительностью роста хвои. Динамика прироста хвои у интродуцентов весьма заметно отличается от таковой у аборигенного вида. Начало роста хвои в значительной степени зависит от температурного режима воздуха. Степень влияния экологических факторов на рост хвои весьма заметно меняется по годам, существенно различаясь у разных видов рода Picea.

Существенное влияние на сроки прохождения большинства фенофаз изученных видов рода Picea оказывает температура воздуха и солнечная радиация.

Наиболее близкими к аборигенному виду по динамике роста побегов и хвои оказались P. glauca и P. pungens. Это свидетельствует о перспективности введения их в культурценозы и создания городских посадок. 


\section{Список литературы / References}

Бабич Н.А. (2008) Интродуценты в зеленом строительстве северных городов: монография. Архангельск, Архангельский государственный технический университет, 144 с. [Babich N. A. (2008) Introduced species in the green construction of northern cities: a monograph. Arkhangelsk, Arkhangelsk State Technical University, 144 p. (in Russian)]

Базилевская Н.А. (1964) Теория и методы интродукциии растений. М., Наука, 130 с. [Bazilevskaya N.A. (1964) Theory and methods of introduction of plants. Moscow, Nauka, $130 \mathrm{p}$. (in Russian)]

Ботенков В.Н., Попова В.Е. (1997) Интродукция высокопродуктивных пород в Сибири. Лесное хозяйство, 5: 44 [Botenkov V.N., Popova V.E. (1997) Introduction of highly productive varieties in Siberia. Forestry [Lesnoe khozyaystvo], 5: 44 (in Russian)]

Буданцев Л.Ю. (1999) Биологическое разнообразие растительного мира, разные аспекты - одна задача. Биологическое разнообразие. Интродукиия растений. Матер. 2-й Междунар. науч. конф. (20-23 апреля 1999 г.). СПб., с. 12-14 [Budantsev L. Yu. (1999) Biological diversity of the plant world, different aspects - one task. Biological diversity. Introduction of plants. Proceedings of $2^{\text {nd }}$ International Scientific Conference (20-23 April 1999). Saint-Petersburg, p. 12-14 (in Russian)]

Булыгин Н.Е. (1979) Фенологические наблюдения над древесными растениями. Л., 97 с. [Bulygin N. E. (1979) Phenological observations of woody plants. Leningrad, 97 p. (in Russian)]

Воробьев Р.А., Тебенькова Д.Н. (2013) Содержание основных пигментов в хвое интродуцентов рода ель в условиях южной тайги (на примере Нижегородской области). Лесоведение, 4: 22-31 [Vorob'ev R.A., Teben'kova D.N. (2013) The main pigment content in needles of introduced spruce in the southern taiga (Nizhnii Novgorod region). Russian Journal of Forest Science [Lesovedenie], 4: 22-31 (in Russian)]

Ворошилов В.Н. (1960) Ритм развития у растений. М., Наука, 312 с. [Voroshilov V.N. (1960) Rhythm of development in plants. Moscow, Nauka, 312 p. (in Russian)]

Встовская Т.Н. (1983) Интродукиия древесных растений дальнего Востока и Западной Сибири. Новосибирск, 196 с. [Vstovskaya T. N. (1983) Introduction of woody plants of the Far East and Western Siberia. Novosibirsk, 196 p. (in Russian)]

Гончарова О.А., Полоскова Е. Ю., Липпонен И.Н. (2015) Фенология интродуцированных видов Picea A. Dietr. на Кольском полуострове. Hortus Botanicus, 10: 189-196 [Goncharova O. А., Poloskova E. Yu., Lipponen I. N. (2015) Phenological development of introduced species Picea A. Dietr. on the Kola peninsula. Hortus Botanicus, 10: 189-196 (in Russian)]

Гортинский Г.Б., Тарасов А.И. (1977) Сравнительная характеристика сезонного прироста сосны и ели в некоторых типах леса. Известия вузов СССР. Лесной журнал, 4: 151-153 [Gortinsky G. B., Tarasov A. I. (1977) Comparative characterization of the seasonal growth of pine and spruce in some types of forest. Bulletin of USSR Higher Educational Institutions. Forestry Journal [Izvestiya vuzov SSSR. Lesnoy zhurnal], 4: 151-153 (in Russian)]

Гурский А.В. (1957) Основные итоги интродукции древесных растений в СССР. М., Л., 140 c. [Gurskiy A. V. (1957) The main results of the introduction of woody plants in the USSR. Moscow, Leningrad, 140 p. (in Russian)]

Зайцев Г.Н. (1981) Фенология древесных растений. М., 119 с. [Zaytsev G. N. (1981) Phenology of woody plants. Moscow, 119 p. (in Russian)] 
Залывская О.С. (2014) Комплексная оценка адаптивной способности интродуцентов. Известия высших учебных заведений. Лесной журнал, 6: 161-166 [Zalyvskaya O.S. (2014) Comprehensive evaluation of adaptive capacity of introduced species. Bulletin of Higher Educational Institutions. Russian Forestry Journal [Izvestiya vysshikh uchebnykh zavedeniy. Lesnoy zhurnal], 6: 161-166 (in Russian)]

Иваненко Б.И. (1962) Фенология древесных и кустарниковых пород. М., Наука, 183 с. [Ivanenko B. I. (1962) Phenology of tree and shrub species. Moscow, Nauka, 183 p. (in Russian)]

Исаев А.С., Носов Л. М., Пузаченко Ю. Г. (1997) Биологическое разнообразие лесов России предложения к программе действий. Сибирский экологический журнал, 4(6): 545-552 [Isaev A. S., Nosov L. M., Puzachenko Yu.G. (1997) Biological diversity of Russian forests - proposals for a program of actions. Siberian Journal of Ecology [Sibirskiy ekologicheskiy zhurnal], 4(6): 545-552 (in Russian)]

Калуцкий К.К., Болотов Н.А. (1983) Биоэкологические особенности лесной интродукции. Лесная интродукиия. Воронеж, с. 4-14 [Kalutskiy K. K., Bolotov N. A. (1983) Bioecological features of forest introduction. Forest introductions. Voronezh, p. 4-14 (in Russian)]

Кищенко И.Т. (1995) Влияние экологических факторов на развитие представителей рода Picea (Pinaceae) в условиях интродукции. Ботанический журнал, 8: 11-18 [Kishchenko I.T. (1995) The influence of ecological factors on the development of representatives of the genus Picea (Pinaceae) under the conditions of introduction. Botanical Journal [Botanicheskiy zhurnal], 8: 11-18 (in Russian)]

Кищенко И. Т. (1998) Сезонный рост хвои представителей рода Picea (Pinaceae) в условиях интродукции. Ботанический журнал, 1: 103-109 [Kishchenko I. T. (1998) Seasonal growth of needles of the representatives of the genus Picea (Pinaceae) in the conditions of introduction. Botanical Journal [Botanicheskiy zhurnal], 1: 103-109 (in Russian)]

Кищенко И.Т. (2000) Рост и развитие аборигенных и интродуцированных видов семейcтва Pinaceae Lindl. в условиях Карелии. Петрозаводск, Изд-во ПетрГУ, 214 с. [Kishchenko I. T. (2000) Growth and development of native and introduced species of the family Pinaceae Lindl. in the conditions of Karelia. Petrozavodsk, Petrozavodsk State University, 214 p. (in Russian)]

Лазарева С. М. (2014) Рост боковых побегов и продолжительность жизни хвои видов Picea в левобережном Заволжье. Хвойнье бореальной зоньь, 32(5-6): 44-49 [Lazareva S.M. (2014) Growth of side shoots and life of needles on the left bank of Picea in the middle Volga. Conifers of the Boreal Area [Hvojnye boreal'noj zony], 32(5-6): 44-49 (in Russian)]

Лапин П.И. (1987) Сезонный ритм развития древесных растений и его значение для интродукции. Бюллетень Главного ботанического сада АН СССР, 65: 12-18 [Lapin P. I. (1987) Seasonal rhythm of development of woody plants and its significance for introduction. Bulletin of the Main Botanical Garden of the USSR Academy of Sciences [Byulleten' Glavnogo botanicheskogo sada AN SSSR], 65: 12-18 (in Russian)]

Лапин П.И., Сиднева С. В. (1973) Оценка перспективности интродукции древесных растений по данным визуальных наблюдений. Опыт интродукции древесных растений. М., с. 7-68 [Lapin P. I., Sidneva S. V. (1973) Estimation of the prospects of introduction of woody plants based on visual observations. The experience of introduction of woody plants. Moscow, p. 7-68 (in Russian)]

Мамаев С. А., Махнев А.К. (1996) Проблема биологического разнообразия и его поддержания в лесных экосистемах. Лесоведение, 5: 3-10 [Mamaev S. A., Makhnev A.K. (1996) Problems 
of biological diversity and its maintenance in forest ecosystems. Russian Journal of Forest Science [Lesovedenie], 5: 3-10 (in Russian)]

Молчанов А. А., Смирнов В.В. (1967) Методика изучения прироста древесных растений. M., 95 c. [Molchanov A.A., Smirnov V.V. (1967) Method of studying the growth of woody plants. Moscow, 95 p. (in Russian)]

Морякина В. А. (1998) Интродукционные фонды растений и их сохранение. Проблемы интродукиии растений и отдаленной гибридизации. Тез. докл. Междунар. конф., посвящ. 100-летию со дня рождения акад. Н. В. Цицина. М., с. 139-140 [Moryakina V. A. (1998) Introduction funds of plants and their conservation. Problems of introduction of plants and remote hybridization. Abstracts of International Conference dedicated to 100-th anniversary of Academician N. V. Tsitsin. Moscow, p. 139-140 (in Russian)]

Паутова Н. В. (2011) Интродукция представителей семейства Pinaceae Lindl. в условиях Европейского Северо-Востока. Вестник ИрГСХА, 44-6: 102-110 [Pautova N. V. (2011) Introduction of the Pinaceae Lindl. family representatives in the conditions of the European north-east. Herald of Irkutsk State Agricultural Academy [Vestnik IrGSHA], 44-6: 102-110 (in Russian)]

Плотникова Л. С. (1983) Научные основы интродукиии и охраны древесных растений флоры СССР: Афтореф. дисс... докт. биол. наук. М., 52 с. [Plotnikova L. S. (1983) Scientific foundations of the introduction and protection of woody flora in the USSR. Theses Dr. Biol. Sciences. Moscow, 52 p. (in Russian)]

Потапова С.А. (1983) Изменчивость длины хвои как показатель успеха адаптации интродуцированных сосен. Древесные растения в природе и культуре. М., Наука, с. 63-67 [Potapova S. A. (1983) Conifer needle length variability as an indicator of the success of adaptation of introduced pines. Woody plants in nature and culture. Moscow, Nauka, p. 63-67 (in Russian)]

Сикура И.И. (1998) Значение интродукции растений в деле сохранения биологического разнообразия видов различных природных флор. Проблемы интродукиии растений и отдаленной гибридизации. Тез. докл. Междунар. науч. конф., посвященной 100-летию со дня рождения акад. Н. В. Цицина. М., с. 186-188 [Sikura I. I. (1998) Importance of introduction of plants in the conservation of biological diversity of species of various natural floras. Problems of plant introduction and remote hybridization. Abstracts of International Conference dedicated to 100-th anniversary of Academician N. V. Tsitsin. Moscow, p. 186-188 (in Russian)]

Смирнов В.В. (1964) Сезонный рост главнейших древесных пород. М., Наука, 167 с. [Smirnov V. V. (1964) Seasonal growth of the main tree species. Moscow, Nauka, 167 p. (in Russian)]

Стецук Н.П., Шонина С. М., Кухлевская Ю. Ф. (2011) Древесные интродуценты в озеленении г. Оренбурга. Вестник ИрГСХА, 44-2: 153-158 [Stetsuk N.P., Shonina S. M., Kukhlevskaya Yu.F. (2011) The introduced species of woods in gardening of Orenburg. Herald of Irkutsk State Agricultural Academy [Vestnik IrGSHA], 44-2: 153-158 (in Russian)]

Трулевич Н.В.(1991) Эколого-фитоиенотические основы интродукиии растения. М., 214 c. [Trulevich N. V. (1991) Ecological and phytocenotic basis of plant introduction. Moscow, 214 p. (in Russian)]

Фролова Л.А. (1979) Влияние температуры на сезонное развитие сосен в Ботаническом саду МГУ на Ленинских горах. Термический фактор в развитии растений различных географических зон. Матер. Всес. конф. М., с. 37-39 [Frolova L. А. (1979) Influence of temperature on the

$$
-257-
$$


seasonal development of pines in the Botanical Garden of the Moscow State University on the Lenin Hills. Thermal factor in the development of plants of different geographical zones. Proceedings of AllUnion Conference. Moscow, p. 37-39 (in Russian)]

Шкутко Н.В. (1973) Зимний покой хвойных интродуцентов. Ритм роста и развития интродуцентов. Тез. докл. Всес. совещ. М., с. 184-187 [Shkutko N.V. (1973) Winter dormancy of coniferous introduced species. Rhythm of growth and development of introduced species. Abstracts of the All-Union meeting. Moscow, p. 184-187 (in Russian)]

Шкутко Н.В.(1991) Хвойные Белоруссии. М., 263 с. [Shkutko N. V. (1991) Conifers of Belarus. Moscow, 263 p. (in Russian)]

Шкутко Н.В., Александрова М.С., Фролова Л.А. (1974) К методике фенологических наблюдений над хвойными растениями в ботанических садах. Бюллетень Главного ботанического сада AH CCCP, 94: 3-10 [Shkutko N. V., Aleksandrova M. S., Frolova L. A. (1974) To the methods of phenological observations of conifers in botanical gardens. Bulletin of the Main Botanical Garden of the USSR Academy of Sciences [Byulleten' Glavnogo botanicheskogo sada AN SSSR], 94: 3-10 (in Russian)]

Bradshaw W.R.H. (1995) The origins and dynamics of native forest ecosystems: background to the use of exotic species in forestry. Buvisindi, 9: 7-15

Damian I., Negrutiu F., Florescu Gh. (1978) Dinamica cresterii molidului in perioda de vegetatie. Nout. Econ. Forest. Univ. Brasov, 12: 55-60

Luomajoki A. (1977) Effects of temperature on spermatophyte male meiosis. Hereditas, 85(1): $33-47$

Rousselet J., Roques A., Garcia J., Rossi J.-P. (2015) An exhaustive inventory of coniferous trees in an agricultural landscape. Biodiversity Data Journal, 3: e4660

Worrall J. (1973) Seasonal, daily, and hourly growth of height and radius in Norway spruce. Canadian Journal of Forest Research, 4: 501-511 